\title{
ARİSTOTELES ESTETİĞİNDE “GÜZEL” İLE “TRAGEDYA” İLIŞKİṠ
}

\author{
Ahmet Çebi1, Zehra Tüten²
}

\section{Özet}

Bu çalışmanın amacı, Aristoteles estetiğinde 'güzel' ile 'tragedya' arasındaki ilişkiyi ortaya koymak, bu iki kavramın nasıl ilişkilendirildiğini ayrıntılarıyla açıklamaktır. Aristoteles Poetika'da "şiir sanatı" olarak da adlandırdığı tragedyayı estetik bağlamda değerlendirme gereksinimi duymuş ve onu 'güzel' ile ilişkilendirmiştir. Bunu yaparken, destanın neden 'güzel' algı alanının dışında kaldığını, komedyanın 'güzel' alg1 alanı içinde yer almasına karşın neden 'güzel' olamayacağını, gerekçeleriyle ortaya koymaya çalışmıştır. Aristoteles estetiğinde 'güzel', göz alg1 alanı içinde var olabilen, "mimesis" kaynaklı bir "büyüklük" ile bir "düzen" gerektirir. Söz konusu 'büyüklük' ile 'düzen', aynı zamanda tragedyanın da olmazsa olmazı olarak kendini gösterir. Aristoteles estetiğinde 'güzel' ile 'tragedya' arasındaki ilişkiyi, bu ilişkinin hangi bağlamlarda, nasıl kurulduğunu, içerik çözümlemesi ve betimsel çözümleme yöntemleriyle ortaya koymayı amaçlayan bu çalışma, alanyazına farklı bir bakış açısıyla yaklaşma denemesidir. Bu çalışmada inceleme sorularını şunlar oluşturmaktadır: (1) Aristoteles estetiği nedir, ondan ne anlaşılmalıdır? (2) Poetika'da "güzel" kavramı nasıl betimlenmiştir? (3) Poetika'da "tragedya" kavramı nasıl betimlenmiştir? (4) Poetika' da "güzel" ile "tragedya" nasıl ilişkilendirilmiştir?

Anahtar kelimeler: Aristoteles estetiği, Güzel, Tragedya

\section{RELATIONSHIP BETWEEN "BEAUTİFUL" AND "TRAGEDY" IN ARISTOTELIAN AESTHETICS}

\begin{abstract}
This study aims to reveal the relationship between 'beautiful' and 'tragedy' in Aristotelian aesthetics and to explain in detail how these two concepts are related. Aristotle needed an evaluation of tragedy, which he called "poetry art" in Poetika, in an aesthetic

\footnotetext{
${ }^{1}$ Dr. Öğr. Üyesi, Ondokuz Mayıs Üniversitesi, Eğitim Fakültesi, Matematik ve Fen Bilimleri Eğitimi Bölümü, ORCID ID: 0000-0003-2622-6297, ahmetcebi@gmail.com 2 Yüksek Lisans Öğrencisi, Ondokuz Mayıs Üniversitesi, ORCID ID: 0000-0002-8804-0394, zehraakara@hotmail.com
} 


\section{ARISTOTELES ESTETİĞINDE “GÜZEL” İLE “TRAGEDYA” İLIŞKİSI}

context and associated it with "beautiful". While doing this, he tried to explain why the epic stays outside the 'beautiful' field of perception and why it cannot be 'beautiful' even though it is within the 'beautiful' perception of comedy, with justifications. In Aristotelian aesthetics, 'beautiful' requires a 'magnitude' and an 'order' originating from 'mimesis' that can exist within the field of eye perception. The 'magnitude' and 'order' in question also manifest themselves as the indispensable of tragedy. This study, which aims to reveal the relationship between 'beautiful' and 'tragedy' in Aristotelian aesthetics, in which contexts and how this relationship is established, with content analysis and descriptive analysis methods, is an attempt to approach the literature from a different perspective. The examination questions in this study are as follows: (1) What is Aristotelian aesthetics, what should be understood from it? (2) How was the concept of "beautiful" described in the Poetics?(3) How was the concept of "tragedy" described in Poetics? (4) How were "beautiful" and "tragedy" related in the Poetics?

Keywords: Aristotelian aesthetics, Beautiful, Tragedy

\section{Giriş}

Burada, çalışmanın sorunu, amacı ve önemi üzerinde durulmuştur.

\subsection{Sorun}

Bilgiyi belirli bağlamlara oturtup dizgeli bir biçimde sunmasıyla ünlenen Antik Çağ düşünürü Aristoteles, fizikten dilbilgisine, birbirine çok uzak görünen alanlarda bile günümüze 1ş1k tutan kaynaklardan biri olarak kendini göstermektedir. Marx (1906: 68), Aristoteles'i, toplum, doğa ve düşünceye özgü birçok biçimi çözümleyen büyük bir düşünür olarak görür. Aristoteles'in çözümlemeye çalıştı̆̆ı, üzerine kafa yorduğu önemli alanlardan biri de estetik ve sanattır. Onun sanata bakışı, hocası Platon gibi değildir.

Platon'a göre şiir tehlikelidir ve kurulu düzen savunucularına karşı kuşku oluşturur, bir drama türü olarak tragedya sanatı da şiirin bu tehlikeli yanını en etkili biçimde ortaya çıkarır (Nutku, 2020: 52). Platon, dramanın bir türü olarak kabul edilen tragedyayı "mimesisin mimesisi" olarak değerlendirip "güzel" bulmadığı için, kurguladığı ülküsel (ideal) devlette onun yerinin olamayacağ1 görüşündedir.

Aristoteles (2017a: 22), hocası Platon'un tersine, tragedyanın korku ve acıma duyguları uyandırarak izleyicilerin ruhunu tutkulardan temizlediğini, ayrıca "güzel" algı alanı içinde bulunduğunu, dahası "güzel" örneği olarak kendini gösterdiğini düşünür. Bu nedenle genel anlamiyla sanat, özel anlamiyla da tragedya, Aristoteles'e göre, toplumsal olarak yararlı olmakla birlikte, kurulu düzenin de koruyucusudur (Thomson, 1990: 426-438).

Tragedyayı toplumsal olarak yararlı bulan ve onun toplumsal düzenin bir tür koruyucusu olma işlevine dikkat çeken Aristoteles (Şener, 2011: 86), dönemin önemli düşünsel sorunsallarından biri olan “Güzel nedir?" konusunu Poetika adlı 


\section{ARISTOTELES ESTETİĞINDE “GÜZEL” İLE “TRAGEDYA” İLIŞKİSI}

yapıtında çok kısaca, ama olabildiğince somut ve oldukça etkili bir biçimde ele alır, tragedyayı "güzel" bulduğunu, onun "güzel" olana örnek oluşturduğunu ileri sürer.

Güzel üzerine yapılan ilk tartışmaları, Antik Çağ filozofları gerçekleştirir (Nascimento, 2018). Aristoteles'in yaşadığı döneme baktığımızda, “Güzel nedir?” düşünsel sorusu, bir sorunsal olarak, "güzelin bilimi" olarak da adlandırılabilen estetiğin temelini oluşturmuştur (Akan, 2012). Aristoteles'e göre, "güzel" olgusunun bulunduğu hemen her yerde "targedya", "tragedya" sanatının olduğu hemen her yerde de "güzel" olgusuyla karşılaşılabilir.

Aristoteles estetiğinde dramanın bir türü olarak kendini gösteren "tragedya" sanatının neden "güzel" bulunduğu, dahası "güzel" olgusuna niçin örnek oluşturduğu, tüm gerekçeleriyle ortaya konulmalıdır. Bu çalışmanın bu bağlamda çıkış noktası, şu sorudur: Aristoteles estetiğinde "güzel" ile "tragedya" nasıl bir ilişki içindedir?

\subsection{Amaç}

Bu çalışmanın amacı, Aristoteles estetiğinde "güzel" ile "tragedya" ilişkisini ortaya koymaktır. Bu amaç doğrultusunda şu sorulara yanıt aranmıştır:

- $\quad$ Aristoteles estetiği nedir, ondan ne anlaşılmalıdır?

- Aristoteles'in yapıtlarında "güzel" kavramına nasıl bakılmakta, "güzel" hangi nitelikleriyle betimlenmektedir?

- Poetika' da "güzel" nasıl betimlenmiştir?

- $\quad$ Poetika' da "tragedya" nasıl betimlenmiştir?

- Poetika' da "güzel" ile "tragedya" nasıl ilişkilendirilmiştir?

\section{3. Önem}

Bireyin, doğanın ve toplumun bilgisinin yanı sıra, güzelin bilginin peşinde bir düşünür gibi koşuşturması, insanlara ve doğaya sanatçı titizliğiyle yaklaşması, çevresindeki her şeyi estetik bir bakış açısıyla inceleyip değerlendirmesi, kendisine ve topluma katkı sağlamaktadır. Sanatla iç içe olan estetik olgusunun bilincine varılması, estetik duyarlılığın kazanılması, günlük yaşamda ve eğitimde büyük önem taşımaktadır. Estetiğe yeterince önem veren bir eğitimin önde gelen ana amaçlarından birkaçı, şöyle sıralanabilir: Özünü bilen, güzel konuşan, düzgün yazma becerisi edinmiş, her ortam ve durumda davranış inceliği gösterebilen, güzellik duygusu taşıyan insanlar yetiştirmek (Kavcar, 2019: 30). İnsanları bu bilince eriştirme doğrultusunda çaba gösterenlerden biri, Dewey, tüm öğretim 


\section{ARISTOTELES ESTETİĞINDE “GÜZEL” İLE “TRAGEDYA” İLIŞKİSİ}

izlencelerinde "sanat odaklı bir öğretim" yaklaşımına yer verilmesinin gerekliliğini vurgular (Özbal ve Aydoğan, 2017: 254).

Sürekli değişen ve gelişen dünyamıza, kendini yetiştirmiş, estetikle donatılmış gerçek bilgi peşinde istekle koşan, yaratıcı bireyler ayak uydurabilecektir. Yaratıcılığ geliştirmenin en önemli yollarından biri, evde, okulda, nerede olursa olsun, sanatla iç içe bulunmak, diğer bir söyleyişle, sanat ürünleriyle içli dişlı olmaktır (Eagleman ve Brandt, 2019: 215-243). Eğitimin sanatla çeşnilendirilebileceği yollardan biri, dramadır. En başa, dramanın ne olduğunun belirlenmeye çalışıldığı döneme gitmek, Aristoteles'e bu bağlamda yeniden bakmak, bir drama türü olarak tragedyanın "güzel" algı alanı içinde yer almasının yanı sıra, "düzen" ve belirli bir "büyüklük" bağlamında niçin Aristoteles estetiğinde onun "güzel" bulunduğunu tüm estetik gerekçeleriyle ortaya çıkarmak, böylece "tragedya" ile "güzel" ilişkisini yerli yerine oturtmak, bir drama türü olarak tragedyanin estetik kökenini irdeleyebilecek yetkinlikte bir bilgiye ulaşmak açısından büyük önem taşımaktadır.

\section{Yöntem}

Bu çalışma, içerik çözümlemesi ile betimsel çözümlemenin temele oturtulması sonucu kendini gösteren, belge incelemesine dayalı nitel bir araştırmadır. Harvey'e göre belge incelemesi, bir belgenin özetini çıkarmak veya açılamasını yapmaktan çok, belgenin içeriğinin çözümlenmesini ve belgenin içerdiği izlek ve izleklere dayalı tüm iletilerin incelenmesini gerektirir (Özkan, 2019: 3). Bu çalışmanın kapsamı ve amacı bağlamında, burada kaynak belge olarak incelenen, öncelikle Aristoteles'in Poetika adlı yapıtı, ardından da Nikomakhos'a Etik, Metafizik, Retorik, Politika adlı diğer yapıtlarıdır.

$\mathrm{Bu}$ araştırmanın verileri, belgesel tarama yöntemiyle toplanmıştır. Belgesel tarama yapılırken kaynaklar bulunur, okunur, not alınır ve değerlendirilir (Karasar: 2016: 230). Karasar'ın sıraladığı veri toplama basamaklarıyla "güzel" ve "tragedya" kavramlarına ilişkin veriler elde edilmiş ve elde edilen veriler değerlendirilmeye alınmıştır.

Araştırma verilerinin çözümlemesinde, içerik çözümlemesi ve betimsel çözümleme yöntemleri kullanılmıştır. İçerik çözümlemesi, metinlerin içindeki belli kavramların, anlamlarını ve ilişkilerini belirlemeye yönelik olarak gerçekleştirilir (Büyüköztürk, vd., 2014: 240). Bu araştırmada, "güzel" ve "tragedya" kavramları, izlek (tema) olarak kendini göstermiş, tümdengelimsel bir yaklaşım benimsenerek içerik çözümlemesi yoluna gidilmiştir.

Betimsel çözümleme, doğrudan alıntılarla beslenerek, bir konunun bir bakıma resmedilmesi, tanımlanması ve açıklanması biçiminde kendini gösterir (Ekiz 2009: 76). Bu araştırma bağlamında gerçekleştirilen çözümleme girişimlerinde, içerik çözümlemesinin yanı sıra, özgünü Yunanca yazılmış Poetika'nın farklı 


\section{ARISTOTELES ESTETİĞINDE “GÜZEL” İLE “TRAGEDYA” İLIŞKİSİ}

çevirilerinden ve zaman zaman da Aristoteles'in Poetika dışındaki yapıtlarından doğrudan alıntılar yapılarak, betimsel çözümleme yoluna da gidilmiştir.

\section{Sonuçlar ve tartışma}

\subsection{Aristoteles estetiği ve Aristoteles'te "güzel" kavramı}

Estetikle ilgili Almanya, Fransa, İngiltere odaklı çalışmalara baktığımızda, estetiğin kurucusu olarak Alexander G. Baumgarten adının öne çıtığını görmekteyiz (Çebi, 1997: 49). Söz konusu sav, şöyle özetlenebilir: Baumgarten, 1735 tarihini taşıyan Şiir Üzerine Bazı Felsefi Düşünceler (Meditationes philosophicae de nonnulis ad poema pertinentibus) başlıklı doktora tezinde, "estetik" kavramından ilk kez söz etmekle kalmamış, estetiğin temellerini açmıştır; ilk cildi 1750 yılında, ikinci cildi 1758 yılında yayımlanan, ancak tamamlanamayan Estetik (Aesthetica) adlı yapıtıyla da, 1735 'teki doktora teziyle açtığı temeller üzerinde mantığın "küçük kızkardeşi" olan estetiği yapılandırarak onun kurucusu olmuş (Tunalı, 1989: 13-15), bir bakıma estetik düzencesini ete kemiğe bürümüştür.

Aristoteles'teki "poetika" kavram1, salt Poetika'daki "güzel" betimlemesinin somut bir temele oturtularak ete kemiğe büründürülme çabasından bile anlaşılabileceği gibi, Baumgarten'in çalışmaları sonucu ilk kez sözcük olarak 18 . yüzyılda kullanılan "estetik" kavramını tüm boyutlarıyla karşılayabilen bir içerik taşımaktadır. Bu nedenle, Poetika'da "estetik" sözcügü geçmiyor diye, Aristoteles'in estetiğin kurucusu olmadığı doğrultusunda hiçbir derinlik taşımayan bir yargıya ulaşmak; Almanya, Fransa, İngiltere odaklı çalışmalarda kendini gösteren bir önyargıyı, estetiğin bağlamını göz ardı ederek yerli yersiz yinelemek, her şeyden önce "şiir sanatı" bağlamında bile resme de, müziğe de can alıcı göndermelerde bulunup gerçek anlamıyla estetiğin kurucusu olarak karşımıza çıkan Aristoteles'e, somut "güzel" üzerine temellendirilen Aristoteles estetiğine haksızlık etmekten başka bir anlam taşımamaktadır (Çebi, 1997: 49-51)

Aristoteles'in kitaplaştırılan notlarını taradığımızda da "güzel" kavramına ilişkin belirli birtakım düşünceler bağlamında önemli ipuçları elde edebiliriz. Bu düşüncelerden ilki, Retorik'te şöyle geçer: "Hem hoş hem de güzel şeylerin iyi olması gerekir. Hoş olan şeyler zevk üretir, güzel olan şeylerin ise bazıları hoştur, bazıları ise kendilerinde arzu edilendir." (Aristotle, 1926: 61). Bunun yanında Aristoteles için bir şeyleri "güzel" bulmak, ruhumuzda gerçekleşen bir olaydır ve ruhta sevdiğimiz şey, "güzel" olandır (Aristoteles, 2014: 32).

Birçok varlığın bilgisinin ya da deviniminin ilkesi, "iyi" ve "güzel" olandır. Ondaki ilke kavramı, bir bilginin ya da oluşun kendisinden çıktığı kaynak olarak tanımlanmaktadır. Örneğin bir çiçeğin varlığının ve deviniminin ilkesi, yani onun kendisinden çıktığı kaynak olarak tohum, "güzel" olanın ta kendisidir (Aristoteles, 1996: 539).

Uluslararası Sanat ve Estetik Dergisi Yıl: 4, Sayı: 7, Aralık 2021 


\section{ARİSTOTELES ESTETİĞİNDE “GÜZEL” İLE “TRAGEDYA” İLIŞKİSi}

Aristoteles'in Metafizik kitabı, "güzel" kavramı için en belirgin anlatımların geçtiği yapıtlardan biridir. Aristoteles, "güzel” kavramını matematiksel boyutuyla bu yapıtta dile getirmiştir. Ona göre, güzellik olgusunun en yüksek biçimleri, düzen, simetri ve belirliliktir (Aristoteles, 1996: 539). Belirlilik, bazı çevirilerde "kesinlik" ve "sınırlılık" olarak da dile getirilmektedir. Burada "güzel" olanın özellikleri biçiminde karşımıza çıkan düzen, simetri, belirlilik, birçok şeyin nedenini oluşturur. Matematiğin de ele aldığı bu tür nedensellikler, "güzel" olanı ortaya çıkarır (Aristotle, 1998: 1078b).

Antik Çağ'da Aristoteles ve diğer filozoflarca zaman zaman dile getirilen "güzel" tanımlamaları, simetri ve oran dengesi biçiminde de kendini gösteren, "altın oran" denilen ölçünün kendine sanatta önemli bir yer edinmesine yol açmış, özellikle de bunun görsel bağlamda sanatın içinde uzun süre "güzellik" ölçüsü olarak kabul görmesini sağlamıştır (Konstan, 2014: 262). Aristoteles'in "şiir sanatı" olarak da adlandırdığı, iki drama türünden biri, dahası en önemlisi olarak belirginleştirdiği "tragedya" türünü "güzel" bulması, onu "güzel” olanın önemli bir örneği olarak görmesi nedeniyle, "güzel" kavramına, yukarıda da belirtildiği gibi, Poetika adlı yapıtında somutluk kazandırmaya çalışmıştır.

\subsection{Poetika' da "güzel" betimlemesi}

Aristoteles, Poetika'da, kendisine değin düzenli bir çerçevesi çizilememiş, dahası pek el uzatılamamış sanat ve estetik alanını irdeler. Araştırmacılarca bazı eksik parçalarının bulunduğu görüşü dile getirilen, sonradan kitaplaştırılmış notlar bütünü olarak kendini gösteren Poetika, sanat ve estetiğe ilişkin kimi el değmemiş konu ve durumların ortaya konulduğu, ortaya konulan bu el değmemiş konu ve durumların da Aristoteles'in dizgeli yaklaşımıla çözümlenip değerlendirildiği bir yapittir.

Aristoteles Poetika'nın ilk bölümünde, şiir sanatının kendisini ve türlerini, bu türlerin tek tek özelliklerinin ele alınması gerekliliğini, sonra da güzel ve başarılı bir yapıt oluşturabilmek için konunun nasıl biçimlendirilmesi gerektiğini belirtir. Cooper'a (1923: 13) göre Aristoteles, sanat üzerine yaptığ 1 incelemeler sonucu, şiir sanatını, epik şiir (destan) ve dramatik şiir olmak üzere iki izlek bağlamında ulamlaştırır. Tragedya ve komedya, dramatik şiir ulamının alt türleri olarak kendini gösterir.

Poetika'nın büyük bir bölümünü, dramatik şiir ulamının bir türü olan tragedya oluşturur. Sonrasında destana yer verilir, ancak bu anlatım, tragedyaya oranla oldukça kısa tutulur. Destandan söz edilen bölümlerde, ölçü, uzunluk, sanatın amacına ulaşıp ulaşamama gibi konularda sık sık tragedya ile destan karşılaştırması yapılır, birçok bakımdan tragedyanın destana üstün tutulduğuna tanık olunur.

Aristoteles, konunun nasıl biçimlendirilmesi gerektiği sorunsalına tragedyayla giriş yapar. Çünkü, Aristoteles'e göre, tragedyanın yapı taşını ve aynı zamanda

Uluslararası Sanat ve Estetik Dergisi Yı1: 4, Sayı: 7, Aralık 2021 


\section{ARİSTOTELES ESTETİĞİNDE “GÜZEL” İLE “TRAGEDYA” İLIŞKİSİ}

ruhunu öykü (mythos) oluşturur (Aristoteles, 2017a: 25). Aristoteles'in Poetika' da öykünün önemiyle ilgili ortaya koyduğu düşünceler, onun çözümleme ve tümevarımı ustalıkla sergilediği bir bileşim niteliğindedir (Myers, 1949: 118).

Aristoteles'e göre yapıtaşı, aynı zamanda ruhu öykü olan tragedya, dizem (ritim), uyum (harmoni) ve şarkı ile süslenmiş bir dil kullanır (her bölümünde ayrı biçimlerde). Tragedya, aynı zamanda, devinen insanların oluşturduğu dramatik eylem ve etkinliklerin yansılamasıdır (Aristotle, 1948: 8). Belirli eylemlerin yansılaması olarak kendini gösteren tragedyanın belli (ortalama 24 saate denk düşen) bir uzunluğu bulunmalıdır. Ayrıca tragedya, bütünlüklü ve tamamlanmış bir eylem olmalıdır (Aristoteles, 2018a: 19). Bütünlüklü derken, başı, ortası ve sonu olan bir öyküden söz edilmektedir. Tragedya öyküsünde bir bütünün parçaları öyle bir araya getirilir ki, en küçük bir yer değişikliği ya da bir parçanın eksikliği, bütünü paramparça eder. Çünkü, tragedyada "varlığı ve yokluğu hissedilmeyen şey bütünün bir parçası değildir." (Aristoteles, 2018a: 22). Tragedyanın "güzel" olabilmesi için, öyküsündeki bütünlüğün korunması ve başı ile sonunun rastgele kurgulanmamış olması gerekir.

Öte yandan nasıl bir şeyin güzel olabilmesi için (ister canlı bir varlık, isterse parçalarla düzenlenmiş bir nesne olsun) yalnızca öğelerinin iyi düzenlenmiş olması yetmiyor, uzunluğunun da rastgele olmaması gerekiyorsa -çünkü güzellik, boyutlarda ve düzende yatar; bu yüzden de güzel bir yaratık ne çok küçük olmalıdır (bu durumda görme yetimiz, algılama sınırlarımızın altında bulanıklaşır) ne de çok büyük (o zaman da bakışlarımızla kavrayamayız onu; bütünlüğünü ve birliğini algılayamayız; birkaç stadion büyüklüguünde bir hayvan düşünün örneğin)- tıpkı bedenlerin ve canlı varlıkların belirli bir boyutta olması ama bunun gözle kavranabilir bir boyut olması, öykülerin de belirli bir uzunluğu olması ama belleğin bunu kolayca kavrayabilmesinin gerektiği gibi... (Aristoteles, 2018b: 33-34).

Aristoteles burada "güzel" kavramını açılarken, ondan öncekilerin de dile getirdiği düzen koşulunun yanına daha önce söylenmemiş olan büyüklüğ̈̈ ekler. Güzel, düzene ve büyüklüğe dayanır. Güzel olan şey, öncelikle gözümüzle algılanabilir olandır. Çünkü görme algı alanımızın dışında kalan küçüklükleri ya da büyüklükleri göremeyeceğimiz için, o şeylerin güzel olup olmamasından söz edemeyiz. Ufuk çizgisine yakın olacak denli küçük bir bakış, belirgin olamaz (Aristotle, 2013: 1451a). Çok büyük bir cisim de gözümüze bütün biçimiyle değil, eksik biçimde görünür ve bu da güzelliğin koşulunu sağlamaz. Örneğin göremeyeceğimiz kadar küçük olan bir insan hücresinin, uygun boyutlarda büyütülmüş biçimi yapıldığı zaman, onun güzelliğinin farkına varabiliriz. Bunun gibi, büyüklüğüyle algı sınırlarımızı fazlasıyla aşan galaksileri, kendi dünyamıza uyarladığımızda, güzellikleriyle ilgili bir düşüncemiz olabilir. Aristoteles'in bu anlayışı kentlerin nüfusunda da kendini gösterir. Her şey için normal bir büyüklük olduğu gibi, kentler için de uygun bir büyüklük olması gerekir. Bir şeyin çok büyük ya da çok küçük olması onun görevini doğru olarak yerine getirmesini engeller. Bu

Uluslararası Sanat ve Estetik Dergisi Y1l: 4, Sayı: 7, Aralık 2021 


\section{ARISTOTELES ESTETİĞINDE “GÜZEL” İLE “TRAGEDYA” İLIŞKİSI}

yüzden nüfus, yönetilemeyecek denli kalabalık bir yapıda olmamalıdır. Bu, düzeni ortadan kaldırır, düzensizlik oluşturur (Aristoteles, 1993: 203).

Aristoteles, çok büyük cisimler için verdiği örnekte "stadion" terimini kullanmıştır. Bu terim, Rifat'ın çevirisinde "birkaç stadion", bazı çevirilerde "on bin stadion" (Sachs, 2006: 30; Benardete and Davis, 2002: 25; Tunalı, 2017a: 28), bazılarındaysa yuvarlanmış kimi anlatımlarla belirtilmiştir. Stadion, o dönem gerçekleştirilen olimpiyat oyunlarında, yarış alanının ölçüsü belirlenmiş uzunluğuna karşılık gelen bir ölçüdür. Bu yarış alanının ölçüsü, birçok çeviride farklı sayılarla dile getirilmekteyse de gözle seçilip algılanabilecek büyüklük, gözün ya da kavrayışın algılayabileceği boyutlardaki cisim ve şeylerin tanımlandığ konusunda hemen herkes aynı düşünceyi paylaşmaktadır. Anlatılmak istenen şudur: Çok büyük bir canlının, cismin ya da şeyin bütününün görülmesi ya da kavranması olanaksızlaşınca, onun "güzel" olarak kabul edilemeyeceğidir. Ayrıca, buna şu görüşü de eklemeliyiz: Görme ya da kavrayış algı alanımız, "güzel” olan her şeyin alanıdır; ancak, görme ya da kavrayış algı alanımıza giren her şey de "güzel" değildir. İşte orada, Poetika'da belirtilenler bağlamında, üzerinde durulan şeyin belirli olmasının yanı sıra, "güzel" olgusunu belirleyen bir düzen (Aristoteles'in Poetika dışında "güzel" kavramına değinen öteki yapıtlarında yer verdiği kavramlara burada bir kez daha göndermede bulunarak söyleyelim), hatta hem simetri, hem oran içeren bir düzen devreye girmektedir.

\subsection{Poetika'da "tragedya" betimlemesi}

Aristoteles, Poetika'da, tragedya yazarı Sophokles ve komedya yazarı Aristophanes'in yapıtlarına göndermede bulunarak, bu yapitlardaki tüm kişilerin dramatik bir eylem ve etkinlik içinde gösterilmesi yoluyla yansılandığını; başka bir söyleyişle, yansılamanın bu yapıtlarda yer verilen kişileri dramatik bir eylem ve etkinlik içinde göstermekle gerçekleştiğini belirtir. Bu nedenle de Aristoteles, sahnelenebilir olma özelliklerinden ötürü, tragedya ve komedya türündeki yapıtların “drama” olarak adlandırılmalarının altını çizer (Aristotle, 1987: 35).

Aristoteles, destan ile tragedyanın ortak yanının soyluları yansılamak olduğunu belirtir, ancak destanın sahnelenebilecek bir uzunluğunun olmadığına, sahnelenmek için çok uzun olduğuna; yine sahnelenme koşulu olarak bir başı ile bir sonunun bulunmadığına göndermelerde bulunur; dolayısıyla, tragedya ve komedya gibi sahnelenememesi nedeniyle, onun "drama" kapsamina alınamayacağını belirgin bir biçimde ortaya koyar. Aristoteles, tragedya ve komedya için üçüncü bir yansılama türünden söz eder. Bu, "olayda yer alan tüm kişilerin eylem ve etkinlik içinde gösterilmesi" biçiminde dile getirilen "rol oynama" etkinliğidir. Rol oynama etkinliği, "drama" olarak adlandırılan komedya ve tragedyaya özgüdür. 


\section{ARISTOTELES ESTETİĞINDE “GÜZEL” İLE “TRAGEDYA” İLIŞKİSI}

Tragedya, ortalamanın üstündeki karakterleri, yani soyluları yansılaması yönüyle komedyadan ayrılır (Aristoteles, 2017a: 14). Soyluları yansılayan tragedya, ahlak bakımından ağırbaşlı (soylu) eylemlerin kendini gösterdiği bir drama türüdür (Aristoteles, 2017a: 22). Tragedyalarda, komedyalardaki gibi ortalama ve ortalamanın aşağısındaki davranışlara, günübirlik kimi sıradanlıklar içeren eylemlere asla yer verilmemekle birlikte, ülküsel (ideal) olanı etkili bir biçimde yansıtma bağlamında, kimi bayağılıklara zaman zaman yer verilebilir; ancak bunlar, tragedyanın ağırbaşlılığını zedelemeyecek bir biçimde, sahne dışında kendini gösteren, dolaylı anlatım yolları da denilebilecek kimi etkilerle (efektlerle) gerçekleştirilir.

Tragedyanın izleyiciye ortalamanın altında yer alabilen sıradan bir haz değil, tragedyaya özgü haz, başka bir söyleyişle, "soylu bir haz" yaşatması beklenir. Bu haz, tragedya öyküsünün içine yerleştirilerek ortaya çıkarılan, acıma ve korku duygularının uyandırılması yoluyla "ruhun tutkulardan temizlenmesi" sözleriyle de dile getirilen armmaya (Aristoteles, 2017b: 49) göndermede bulunmaktadır. Acıma ve korku duygularının ortaya çıkarılması, tragedya izleyicisinin katharsis yaşamasına yol açar (Aristoteles, 2018a: 15). Katharsis, en yalın anlatımıyla, "duygularda arınma" olarak da adlandırılmaktadır.

\subsection{Poetika'da "güzel" ile "tragedya" ilişkisi}

Aristoteles, güzelin iki koşulunu dile getirdikten sonra, bir tragedya öyküsünün de belirli bir büyüklüğü yakaladığı zaman ancak güzel olabileceğini vurgular. Burada sözü edilen büyüklük, oyunun uzunluğu, yani süresidir (Nutku, 2020: 42). Tragedyanın güzel olması için süresinin hangi uzunlukta olması gerekir? Poetika'da belirtildiğine göre, güzel bir öykünün, izleyicilerin onu bütünlüklü bir biçimde anımsamasını sağlayacak sürede gerçekleşmesi gerekir (Aristoteles, 2018a: 20).

Düşünelim ki izleyici sahnelenen bir tragedya yapıtını izliyor, olay örgüsünün çok kısa, ya da çok uzun bir süreyi kapsaması, tragedya için ortalama süre olarak gösterilen 24 saatlik sürenin çok altında kalması ya da ortalama süreyi kat kat aşması, birtakım durumların ortaya çıkmasına yol açacaktır. Böyle bir durumda, ya çok kısa bir süreye çok yoğun bir olay örgüsünün tıkıştırılıp öykünün boğulması nedeniyle öykü izleyicinin kavrayış alanının dışında kalacak; ya da ortalama sürenin çok üzerinde bir zaman süresine yayılacak çoğu gereksiz olaylar dizisinin oyuna boca edildiği bir durumda da oyun izleyicinin kavrayış alanının dışına çıkacaktır. Kısacası, Aristoteles'e göre "güzel" olgusunun iki ölçütünün, düzen ve büyüklük koşullarının bu türden oyunlarda ortadan kaldırılması nedeniyle, Aristoteles estetiği bağlamında her iki tür oyunun da kabul görmesi olanaksızlaşacaktır. 


\section{ARİSTOTELES ESTETİĞİNDE “GÜZEL” İLE “TRAGEDYA” İLIŞKİSİ}

Eskiden tragedyaları yarıştırmak gerektiğinde, bunu su saati ile yaparlarmış. Aristoteles bu gibi yarışmaların yapılmasından ve izleyicilerin kalabalık oluşturmasından yana değildir. Aristoteles'e göre, süreyle ilgili bu tür durumlar, yani salt yapıtın süresinin yapıtın sanatsal değerini belirleyen bir etmen olmadığı görüşündedir (Aristotle, 1987: 39). Tragedyaların süresi, Aristoteles'e göre, bu gibi durum ve koşullara göre değil, nesnenin doğasından kaynaklanan sinırlara göre belirlenmelidir. Aristoteles estetiğinde bu sinır şudur: Düzen ve büyüklük ölçütlerini göz ardı etmemek, yani kavranılırlığın korunması koşuluyla, en uzun zamana yayılan tragedya öyküleri, en "güzel” öykülerdir (Aristoteles, 2018b: 34).

Aristoteles estetiği bağlamında tragedya öyküsünün süresi için genel bir sanatsal sınır oluşturulduğunda, şu söylenebilir: Öykünün süresi, doğal ve kaçınılmaz bir sırayla, birbirine bağlanan bir dizi eylemle, kahramanın mutluluktan sefalete düşmesine veya sefaletten mutluluğa yükselmesine izin verecek bir uzunlukta olmalıdır (Cooper, 1923: 42). Doğal ve kaçınılmaz bir sıra ile birbirini izleyen tragedya öyküsünün eylemleri, çoğu Poetika çevirinde "olasılık ve zorunluluk yasaları gereği gerçekleşen olaylar" biçiminde yer almıştır.

Nutku'ya (2020: 42) göre olasılık, tragedya içinde olabilecek bir olayın akla, mantığa ve duyguya uygun düşecek biçimde gelişmesidir. Zorunluluk ise birbirini izleyen eylemlerin belli bir düzen içerisinde birbirlerine bağlı olmasıdır. Bir eylemin kaçınılmaz bir biçimde başka bir eylemi oluşturması ve birbiri ardınca sıralanmasıdır. Else, güzelliğin ayrıcalığı olan, olasılık ve zorunluluk gereği gerçekleşen bu kaçınılmazlık duyumunun, tragedyadaki gerçek duyguyu ortaya çıkardığını belirtmiştir (Else, 1938: 198). Kahramanı bekleyen kaçınılmaz son, Aristoteles estetiği bağlamında, tragedyanın vermesi gereken duyguları açığa çıkarır.

Aristoteles, katharsis belirlemesiyle, tragedyanın vermesi gereken iki duygudan birinin actma, diğerinin korku olduğunu belirtir. Acıma, Aristoteles estetiğinde, yaşadıklarını hak etmeyen kişilerle izleyicinin duygudaşlık kurması sonucunda; korku, adı geçen estetik bağlamında, izleyicinin o kişilerle kendi arasında benzerlik bulup duygudaşlık duyması sonucu gerçekleşir (Aristotle, 2002: 33). Aristotelesçi estetikte duyguların beklenen yoğunlukta dile getirilmesi, bunun izleyenlerce duyumsanması, duygudaşlı̆̆a (empatiye) yol açan sahnelere gereken biçimde yer verilmesi, tragedyanın etkisini artıran etmenlerden biri olarak kendini gösterebilir. Aristoteles Retorik'te, anlamı kesinlik gösteren bir söz söylememesine karşın, yalnızca duygularını dile getiren kişiye, dinleyip izleyen kimselerin sempati duyacağını belirtir (Marincola, 2003: 292). Öyleyse, Aristotelesçi estetik bağlamında, tragedyanın temellerine yerleştirilmeye çalışılan acıma ve korku duygularını duyumsayanlar, yaşadıklarından haz duyacak, haz duyduğu duruma karşı sempati besleyeceklerdir.

Aristoteles estetiğine göre, ne mutluluktan sefalete düşen "iyi" insanlar, ne de sefaletten mutluluğa yükselen "kötü" insanlar, bir başlarına, acıma, korku ya da

Uluslararası Sanat ve Estetik Dergisi Yı1: 4, Sayı: 7, Aralık 2021 


\section{ARISTOTELES ESTETİĞINDE “GÜZEL” İLE “TRAGEDYA” İLIŞKİSI}

yalın bir sempati duygusu uyandırabilir. Örgüsü sağlam kurulmuş bir öykü, Aristotelesçi estetiğe göre, kişilerin sergilediği ahlak dışı davranışlar yüzünden değil, ciddi bir hata yüzünden iyi şanstan kötüye ya da mutluluktan sefalete sürüklenen birinin değişimini içermelidir (Aristotle, 2013: 1453a). Öykülerdeki geçişlerin bu doğrultuda olması ve buna yetecek zamanın sağlanması, "güzel" bir tragedya öyküsünün Aristotelesçi estetik bağlamında kurgulanmasının ön koşullarından biridir.

Aristoteles'in düzen ve büyüklük ölçütlerine dayanan "güzel" anlayışının, öykünün uzunluğuna getirdiği koşulları sırasıyla gözden geçirmeye çalıştık. Şimdi buraya dek üzerinde durduğumuz soruyu burada yeniden soralım: Bu ölçütler bağlamında, öykü uzunluğu somut olarak ne olmalıdır? Aristoteles, destan ile tragedyayı karşılaştırdığı bölümlerde, destanın süre sınırlamasının olmadığını belirtir ve tragedyanın olması gereken uzunluğunu en açık biçimde şu tümceyle dile getirir: “Tragedya, elden geldiğince güneşin bir günlük dönüşüyle sinırlar kendini ya da bunu çok az aşar; oysa destan zaman içinde sınırlanmamıştır" (Aristoteles, 2018b: 28). Güneşin bir günlük dönüşü anlatımıyla 24 saatlik bir süre anlaşılmaktadır. Bu açıklamaya göre destanın konusu haftaları, ayları, yılları içerebilirken, tragedyanın konusu, en fazla bir gün içinde, bütünlüklü bir biçimde tamamlanmalıdır (Nutku, 2020: 43).

Aristoteles'e göre, izleyicilerin, belirli saatler içerisinde canlandırılan bir eylemin aslında birkaç yıl sürdüğüne inanmasını beklemek, mantıksız olurdu (Valency, 1979: 335). Tragedyada bir olay, "güzel" olgusunun kavranılabilirlik ölçütleri bağlamında, bir gün içinde, bir yerde, izleyenlerin tanıklığında yaşanıp biterdi. Tragedyanın konusunun tek bir gün ile sınırlandırılması, sonraları eylem, zaman ve yer birlikteliğine göndermede bulunan "Üç Birlik Kuralı" biçiminde kendini yapılandırmıştır.

Belirtilen düzen ve büyüklük ölçütleri, tragedyanın yanı sıra, bir başka drama türü olan komedya için de sağlanıyormuş gibi gözükmektedir. Ancak, tragedyayı "güzel" bulan Aristoteles, komedyayı "güzel" bulmaz. Bunun nedenini şöyle açıklayabiliriz: Komedyanın "güzel" alg1 alanında bulunup kavranılabilirlik yeterliliğini taşıyormuş gibi gözükmesine karşın, kavranılabilirlikteki düzen ile büyüklük ölçütlerini, tragedyada olduğu gibi, simetriklik ve orantılllı özellikleriyle de karşılaması söz konusu mudur? Aristotelesçi estetiğe göre, ortalamanın aşağısındaki "bayağı" ve "gülünç" karakterleri yansılayan komedya, yapısına da "bayağ1" ve "gülünç" özellikler sinmesi nedeniyle, kavranılabilirlik alg1 alanında bulunsa bile, düzen ve büyüklük bakımından soylulara özgü eylemlerde kendini gösteren simetriklik ve orantıllık özelliklerini taşıyamaz, dolayısıyla Aristoteles estetiği bağlamında "güzel" olamaz. Çünkü, "bayağı" ve "gülünç" özellikler taşımak, Aristoteles'e göre, soyluluğa yaraşmaz.

Uluslararası Sanat ve Estetik Dergisi Y1l: 4, Sayı: 7, Aralık 2021 


\section{ARISTOTELES ESTETİĞINDE “GÜZEL” İLE “TRAGEDYA" İLIŞKİSİ}

\section{Kaynakça}

Akan, N. (2012). Platon'da Müzik. İstanbul: Bağlam.

Aristoteles (1993). Politika. Mete Tuncay (Çev.). İstanbul: Remzi Kitabevi.

Aristoteles (1996). Metafizik. Ahmet Arslan (Çev.). İstanbul: Sosyal Yayınlar.

Aristoteles (2014). Nikomakhos'a Etik. Furkan Akderin (Çev.). İstanbul: Say.

Aristoteles (2017a). Poetika. İsmail Tunalı (Çev.). İstanbul: Remzi Kitabevi.

Aristoteles (2017b). Poetika. Nazile Kalaycı (Çev.). Ankara: Pharmakon.

Aristoteles (2018a). Poetika. Ari Çokona ve Ömer Aygün (Çev.). İstanbul: İş Bankası Yayınları.

Aristoteles (2018b). Poetika / Şiir Sanatı Üstüne. Samih Rifat (Çev.). İstanbul: Can Sanat Yayınları.

Aristotle (1926). The "Art" of Rhetoric. John Henry Freese (Trans.). London: William Heinemann.

Aristotle (1948). On the Art of Poetry With a Supplement on Music. S.H. Butcher (Trans.). New York: The Liberal Arts Press.

Aristotle (1987). The Poetics of Aristotle. Stephen Halliwell (Trans.). Chapel Hill: The University Of North Carolina Press.

Aristotle (1998). Metaphysics. Hugh Lawson-Tancred (Trans.). London: Penguin Books.

Aristotle (2002). On Poetics. Seth Benardete and Michael Davis (Trans.). Indiana: St. Augustine's Press.

Aristotle (2013). Poetics. Anthony Kenny (Trans.). Oxford: Oxford University Press.

Büyüköztürk, Ş.; Çakmak, E. K.; Akgün, Ö. E.; Karadeniz, Ş.; Demirel, F. (2014). Bilimsel Araştırma Yöntemleri. Ankara: Pegem Akademi.

Cooper, L. (1923). The Poetics of Aristotle Its Meaning and Influence. Massachusetts: Marshall Jones Company.

Çebi, A. K. (1997). Estetikte “Güzel” in Konumlandırılışı, Kavram ve Karmaşa. 4, 49-51.

Eagleman, D. ve Brandt, A. (2019). Yaratıcı Tür. Zeynep Arık Tozar (Çev.). İstanbul: Domingo.

Ekiz, D. (2009). Bilimsel Araştırma Yöntemleri. Ankara: Anı Yayıncılık.

Else, G. F. (1938). Aristotle on the Beauty of Tragedy. Harvard Studies in Classical Philology. 49. 179-204.

Karasar, N. (2016). Bilimsel Araştırma Yöntemi: Kavramlar, İlkeler, Teknikler. İstanbul: Nobel Akademik Yayıncilık.

Kavcar, C. (2019). Yeni Türk Edebiyatı Öğretimi. Ankara University Journal of Faculty of Educational Sciences (JFES). 26 (1). 29-38. DOI: 10.1501/Egifak_0000000526

Konstan, D. (2014). Beauty: The Fortunes of an Ancient Greek Idea. New York: Oxford University press.

Marincola, J. (2003). Beyond Pity and Fear: The Emotions of History. Ancient Society. 33. 285-315.

Marx, K. (1906). Capital a Critique of Political Economy. Ernest Untermann (Trans.). New York: The Modern Library.

Myers, H. A. (1949). Aristotle's Study of Tragedy. Educational Theatre Journal. 1 (2). 115-127.

Nascimento, M. L. F. (2018, April). Aesthetical Beauty of Mathematics and the Pythagorean Theorem. 3rd Annual International Conference on Education Science and Education Management, Wuhan.

Nutku, Ö. (2020). Dram Sanatı-Tiyatroya Giriş. İstanbul: Kabalcı.

Uluslararası Sanat ve Estetik Dergisi Yıl: 4, Sayı: 7, Aralık 2021 


\section{ARİSTOTELES ESTETİ̆İNDE “GÜZEL” İLE “TRAGEDYA” İLIŞKİSI}

Özbal, N. ve Aydoğan, İ. (2017). Eğitimde Estetiğin Gerekliliği ve Oluşumu Üzerine Bir İnceleme. Kırıkkale Üniversitesi Sosyal Bilimler Dergisi. 7(2), 249-260.

Özkan, U. B. (2019). Eğitim Bilimleri Araştırmalan İçin Doküman İnceleme Yöntemi. Ankara: Pegem Akademi.

Şener, S. (2011). Dram Sanatı. İstanbul: Mitos- Boyut Yayınları.

Thomson, G. (1990). Aiskhylos ve Atina. Celal Üster (çev.). İstanbul: Payel Yayınevi.

Tunalı, İ. (1989). Estetik. İstanbul: Remzi Kitabevi.

Valency, M. (1979). Drama. The Encyclopedia Americana (Vol 9, 333-357). Danbury: Americana Corporation. 